\title{
Doğa, İnsan ve Teknik: \\ 2001: Bir Uzay Macerası'nı Heidegger'le İzlemek ${ }^{1}$
}

Deniz Kurtyılmaz*

\section{Özet}

İnsan, kendisine mahsus bir bilinç sayesinde doğayı aşmakta ve bir uygarlık meydana getirmektedir. Duyulur dünyanın ötesinde bir gerçekliği sezme anlamında metafizik bir canlı olan insan, bu yetisi ile tekniği yaratarak doğayı egemenliği altına alır. Doğaya boyun eğdirme serüveni, bilincin ortaya çıkmasıyla başlamışsa da modern çă̆ın gelişiyle iyiden iyiye hızlanmıştır. Fakat tam bu noktada, insanın kendi ürünü olan teknik, denetimden kurtulup, insanoğlunu kendi dayattı̆̆ bir var olma biçimine hapsetme tehdidini de taşımaktadır. Alman düşünür Heidegger'in felsefesinde izi sürülebilecek bu düşünceler ABD'li yönetmen Stanley Kubrick'in 2001: Bir Uzay Macerası adlı filminde de açıkça görülebilir. Bu anlamda çalışmamız, Kubrick'in filmini Heidegger'in tekniğe ilişkin düşünceleri ekseninde felsefi bir analize tabi tutmaktadır. Çalışma boyunca, filmin anlatısı ve felsefi düşünceler beraberce ele alınarak doğa, insan ve teknik arasındaki ilişkinin açı̆̆a çıkarılması amaçlanmıştır.

Anahtar Kelimeler: İnsan, doğa, teknik, Heidegger, Kubrick.

\footnotetext{
${ }^{1}$ Bu çalışma, Stanley Kubrick'in 1968 yapımı 2001: Bir Uzay Macerası filminin 50. yılı bağlamında kaleme alınmıştır.

${ }^{*}$ ORCID ID: https:/ / orcid.org/0000-0001-8123-8034

E-mail: denizkurtyilmaz@hotmail.com

DOI: $10.31122 /$ sinefilozofi.405438

Geliş Tarihi - Received: 13.03.2018

Kabul Tarihi - Accepted: 14.06.2018
} 


\title{
Nature, Man and Technique: \\ Rewatching 2001: A Space Odyssey with Heidegger
}

\author{
Deniz Kurtyılmaz*
}

\begin{abstract}
Man transcends the nature through a consciousness of his own, and brings a civilization into being. Man, who is a metaphysical creature in the meaning of sensing a reality beyond the perceptible world, hegemonizes the nature by creating technique with that sense. Although adventure of subjugation to nature began with the emergence of consciousness, it has accelerated fully by the advent of modern age. However, at this point, his own output, technology of man, also contains the danger of escaping from supervision and imprisoning mankind in a form of existence that it imposes. These thoughts, which can be traced in the philosophy of the German thinker Heidegger, can also be clearly seen in American director Stanley Kubrick's 2001: A Space Odyssey. In this sense, our work subjects the Kubrick's film to a philosophical analysis in the line with Heidegger's thought on the technique. Throughout the study, it was aimed to expose the relationship between nature, man and technique by addressing the narrative and philosophical thoughts together.
\end{abstract}

Keywords: Man, nature, technique, Heidegger, Kubrick.

* ORCID ID: https://orcid.org/0000-0001-8123-8034

E-mail: denizkurtyilmaz@hotmail.com

DOI: $10.31122 /$ sinefilozofi. 405438

Received - Geliş Tarihi: 13.03.2018

Accepted - Kabul Tarihi: 14.06.2018 


\section{Giriş: Sınırlar, Uygarlık ve Teknik}

Vercors takma adını kullanan Fransız yazar Jean Bruller'in 1952 yılında okuyucusuyla buluşmuş Les Animaux Dénaturés adlı ilginç bir romanı vardır. Soysuzlaşmış Hayvanlar (1965) adıyla dilimize de çevrilmiş olan roman, bir grup insanın, evrim basamağında insanla maymun arasında bulunması gerektiğine inanılan bir geçiş türünün kemiklerini aramak üzere yola çıkmasıyla başlar. Keşif grubu, yolculuğunun sonunda umduğundan çok daha fazlasıyla karşılaşarak Yeni Gine'nin sık ormanlarında türün bizzat kendisini buluverir. Bu, bilim açısından muazzam bir buluş olsa da, yeni bir tartışmayı, bir sınır sorununu ${ }^{2}$ da beraberinde getirir: Bulunan yeni tür maymun mudur, yoksa insan mı?

Bir dizi olayın neticesinde, bu sorunun cevaplanması keşfedilen türe karşı muamelatı tamamıyla değiştireceği için son derece önemli hâle gelir ve mesele İngiliz Yüksek Mahkemesi'ne taşınır. Fakat ne mahkeme başkanı yargıç ne de jüri, bulunan yaratıkların ne olduğuna karar verebilir. Yargıç çaresizlik içinde düşünürken, eşi dolaylı olarak, onu cevaba götürecek bir bakış açısı getirir: Önce insanın ne olduğunu tanımlamak gerekmektedir. İnsanın ne olduğunu tanımlamak için kullanacağımız ölçüt, insanla hayvan arasındaki sınırı da belirleyecektir.

Yargiç bu ölçütün ne olduğu konusunda kendisinden emindir; ona göre insan metafizik bir canlıdır. Vercors'un eserinde metafizik, insanda, doğanın içinde ama aynı zamanda onun ötesinde bir varlık anlayışının kendisini göstermesidir; doğadan fikren ayrılmak demektir: "Tabiatla eş olan hayvan, ona soru soramaz. Hayvanla tabiat, bir eder. İnsanla tabiat ise $i k i$ eder. Pasif şuursuzluktan soran şuurluluğa geçmek için bu ayrılmanın, bu 'boşanmanın', bu kopmanın olup bitmesi gerekmiştir. İşte aradaki sınır da tam bu değil midir? Yani kopmadan önce hayvan, ondan sonra insan değil midir?" (Vercors, 1965: 199-200). Böylece, Aydınlanma düşünürü Jean-Jacques Rousseau'nun henüz 18. yüzyılda dile getirdiği "insan doğanın içinde kendisine has bir aşırılık içindedir, oysa hayvan doğanın içinde erimiş bir varlıktır" (Rousseau, 1995: 49) savı Vercors' un romanında bir ana fikir olarak tekrar edilmiş olur ve çalışmamız için de bir Arşimet noktası hâline gelir.

İnsana özgü bu aşırılık doğada asla göremeyeceğimiz yapay bir şeyi; uygarlığı yaratmaktadır. İnsanoğlu, uygarlığını, doğaya onto-lojik ve teknik bir şiddet uygulayıp onu dönüştürerek, doğayı kendi başına asla olamayacağı hallere sokarak üretir. Daha açı bir ifadeyle, kendine has var olma biçimi insanı doğaya yabancılaştırmakta, yabancılaşma da onu başka hiçbir canlıda göremeyeceğimiz bir bilinç durumuna yükseltmektedir. Söz konusu bilinçse, matematik gibi (doğaya uygulanması mümkün olsa da doğadan deneye dayalı yollarla devşirilemeyen) soyut rasyonel edimleri ve teknik gibi (doğayı insanın egemenliğine

\footnotetext{
2 Tam Türkçe karşıllığı “Doğal Olmayan Hayvan” olarak verilebilecek kitabın adının İngilizceye, "sınır" anlamına gelen "Borderline" olarak çevrilmesi de bahsettiğimiz şekliyle insan ve doğa arasındaki hudut meselesine gönderme yapması açısından oldukça anlamlıdır. (Bkz.: Vercors. (1976). Borderline (Translated by R.Barisse), New English Library Ltd., https://www.amazon.com/ 29980)
} 
koşan) pratik sonuçları da içeren tamamen insana özgü bir bilinçtir ve uygarlığımızın temelini oluşturur.

Hem rasyonel düşünce hem de ürettiğimiz teknik, çalışmamız açısından bakıldığında son derece önemlidir. Zira şu an içinde yaşadığımız medeniyetin, çeşitli kesintileri ve sıçramaları da ihtiva eden bir devamlılık içinde, (özellikle 17. yüzyıldan sonra giderek artan bir ivmeyle) rasyonel/matematikçi dünya görüşü ve etki sahası gün geçtikçe artan bir teknik sayesinde yaratıldığı herkesin kabul edebileceği bir gerçektir. Modern çağın, insan ve doğa arasında en başından beri var olan karşıtlı̆̆ın giderek derinleşmesiyle; sonunda aşılamaz duruma gelmesiyle ortaya çıktığı görülür.

Başka bir ifadeyle, zaten doğanın içinde gömülü olmayan insan, modern dönemle birlikte onu aşmakla kalmamış, büsbütün karşısına almıştır. Artık, doğayla ilk elden bir ilişkiye de giremez. İnsanî bir yapı ve öznenin inşası olarak doğa ile ilişkisi, rasyonel düşünce ve ürettiği teknik vasıtasıyla dolayımlanmış bir duruma girmiştir (Özlem, 1998: 19). Basit aletlerin üretiminden başlayan teknik, insanın doğa üzerinde egemenlik kurma düşünü, tam da bahsedilen dolayım sayesinde gerçek kılmıştır.

Fakat Alman düşünür Martin Heidegger'in belirttiği gibi tekniğin özünde çok dikkat edilmesi gereken bir tehlike de bulunmaktadır: "Tekniğe hâkim olma iradesi ne kadar elzem hâle gelirse, teknik de o kadar insanın denetiminden kaçıp kurtulma tehdidinde bulunur" (Heidegger, 1998: 45). 1889 ile 1976 yılları arasında yaşamış Heidegger'in, insan ve teknik arasındaki ikircikli ilişkiye dair henüz 20. yüzyılın ilk yarısında ifade ettiği kaygısını bugün giderek daha çok insanın taşımaya başladığını söyleyebiliriz. Aynı şekilde, söz konusu kaygı kendisini sinema perdesinde de uzunca bir süredir göstermektedir. İnsanın doğa üzerinde egemenlik kurmak için ürettiği fakat sonunda bağımlı olduğu bir araç olan teknik'e ve onun insanoğluna yapabileceklerine dair -çoğu zaman- kötümser filmler uzunca bir liste oluştursa da, bu filmlerin şüphesiz ki en etkileyicilerinden biri 2001: A Space Odyssey (2001: Bir Uzay Macerası, Stanley Kubrick, 1968) adlı yapıttır. ABD' li yönetmen Stanley Kubrick'in eseri doğa, insan ve teknik meselesini yukarıda ele almaya gayret ettiğimiz serencamı içinde değerlendiren bir film olarak öne çıkmakta ve bu yönüyle bir Heidegger okuması yapmak için de son derece elverişli bir alan haline gelmektedir.

Bu bağlamda çalışmamız 2001: Bir Uzay Macerası filmini, Alman felsefeci Martin Heidegger' in düşünceleri ekseninde felsefî bir okumaya tabi tutmaktadır. 1968 yapımı olan ve bu yıl elli yaşını dolduran filmi analiz eden çalışmamız, insan, teknik ve varlık arasında giderek daha sorunlu hale gelen ilişkiyi büyük ölçüde eleştirel bir perspektiften ortaya koymayı amaçlamaktadır. Filmin bölümlerini, eserin tamamına gönderme yapacak biçimde metonimik olarak inceleyen çalışmamızda, önce felsefi bir teorik kısım oluşturup sonra analize koyulmak yerine, filmin anlatısı ve felsefî değerlendirmelerin beraberce ele alınması yoluna gidilmiştir.

\section{1. İnsanoğlunun Şafă̆ı: Bilinç Doğuyor}

Stanley Kubrick'in, senaryosunu ünlü bilimkurgu yazarı Arthur C. Clarke'la birlikte yazdığı film, The Dawn of Man (İnsanoğlunun Şafağı) adlı, bir bilimkurgu için oldukça sıra dışı 
bir bölümle açılmaktadır. Detaylı biçimde ele alınmak durumunda olan bölüm, günümüzden milyonlarca yıl önce, yaklaşık on beş - yirmi kişilik gruplar halinde yaşayan ve insan türünün atası olan maymunsu canlıların yaşamını anlatmaktadır. Henüz insandan çok maymunu andıran bu canlılar, çığlık benzeri basit sesler çıkarmak dışında konuşamazlar. Yalnızca toplayıcı olan tür, etrafındaki tapirleri ${ }^{3}$ avlayıp yemek yerine onlarla bir arada yaşamaktadır. Ortalıkta görünen kemiklerden anlaşıldığı kadarıyla ölülerini gömmeyen maymunsular, her an bir yırtıcıya yem olabilme korkusunu duymaktadırlar. Ayrıca, bu canlılar ihtiyaç duydukları su için bir gölete gitse de suya ulaşabilmek için kendilerinden çok daha kalabalık diğer gruplarla çatışmak zorunda kalırlar ve verdikleri mücadelede başarısız olan sürü belli ki çoğu zaman mağarasına susuz dönmektedir.

Fakat bir sabaha karşı, tan kızıllığ mağaranın girişinde birdenbire siyah bir monolit (dikilitaş) belirir. Maymunsular önce ansızın ortaya çıkan bu dikilitaş sebebiyle dehşete düşseler de zamanla merakları korkularını galebe çalar ve ona yaklaşmaya başlarlar. Sonunda, primatlardan birisi dikilitaşa dokunmaya cesaret edecektir. Devamındaysa, diğerleri de teker teker taşa dokunmaya başlar. Tüm grup üyelerinin dikilitaşa dokunmasının ardından güneşin monolit üzerinden doğduğu görülür: Şafak sökmüştür.

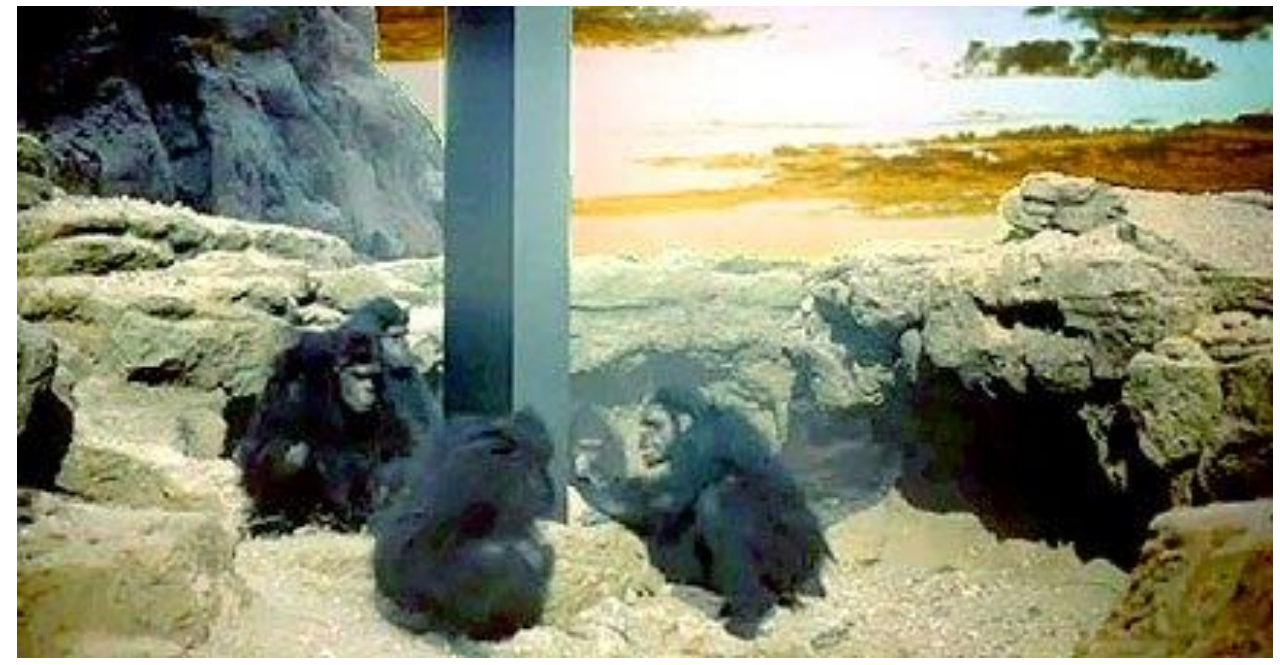

Görsel 1: Maymunsular ve Monolit

Güneş iyice yükseldiğinde, sürü yaşamına kaldığı yerden devam ediyormuş gibi görünse de bu kez farklı şeyler olacaktır. Primatlardan biri yerde duran bir hayvan iskeletine birden dikkatle bakmaya başlar. Bu sahnede, monolitin üzerinden güneşin doğduğu an yine beliriverir (Görsel 2). Primat, dikkatle baktığı iskelete ihtiyatla yaklaşır ve çekip aldığı bir uyluk kemiği ile diğer kemiklere vurmaya başlar. Elindeki büyük kemiğin diğerlerini kırdığını fark edince çok daha sertçe ve istekle vurur. Yerdeki kafatasının kırıldığı anda, koşut kurguyla tapirlerden birinin de yere yığıldığı görülür. Maymunsu kemikleri şevkle kırmaya devam

3 Dünyanın tropikal bölgelerinde küçük sürüler halinde yaşayan toynaklı, kısa hortumlu, domuz benzeri bir hayvan. 
eder. Akşam olduğundaysa sürünün tamamı öldürdükleri tapirlerin etini yemektedir. Demek ki ilk av aleti bulunmuştur.

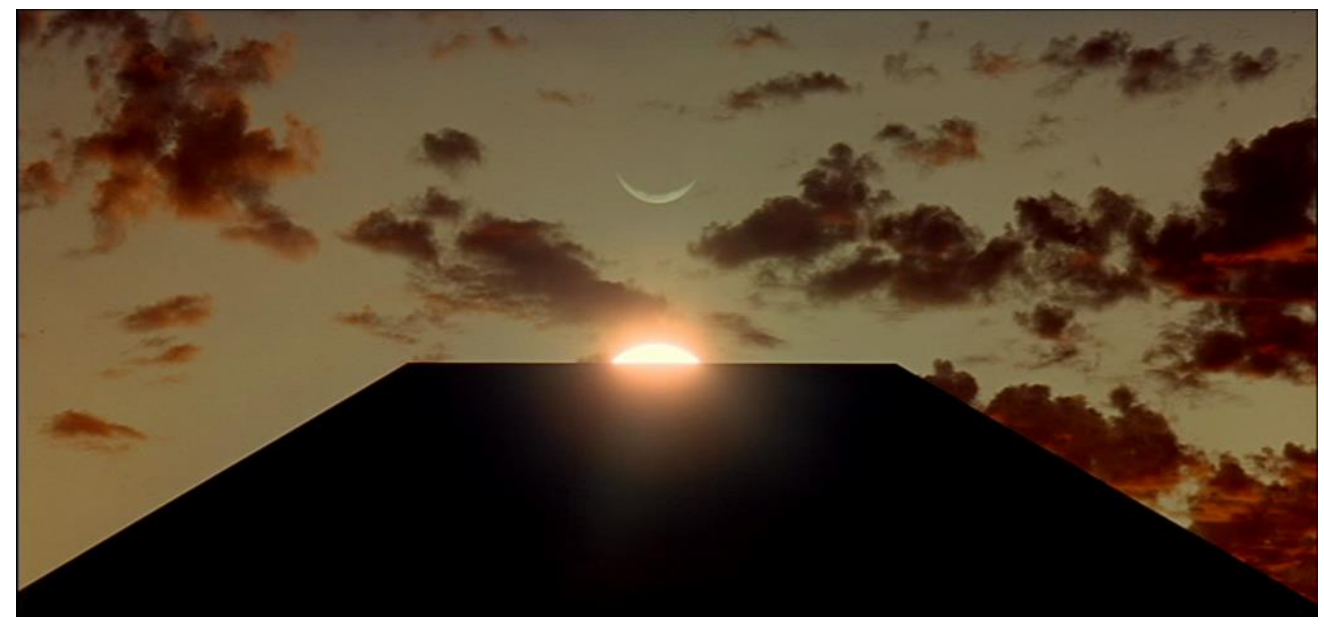

Görsel 2: Monolitin Üzerinden Doğan Güneş

Ertesi sabah, primatlar su ihtiyacını karşılamak için gölete iner. Başka bir grup yine oradadır ve onları suya yanaştırmak istemez. Fakat bu kez farklı olacaktır. Ellerinde uzun kemikler taşıyan maymunsulardan bir tanesi, karşı grubun liderinin başına vurur ve onu yere serer. Liderlerinin yere yığıldığını gören diğer grubun üyeleri korkuyla kaçarlar. Böylece ilk cinayet aleti de icat edilmiştir. Sonunda suya kavuşan maymunsu, sevinç çığlıkları atarak elindeki kemiği havaya fırlatır ve kamera kemiği takip eder. Havada süzülen kemik, bir kesme sayesinde, uzayda yol alan bir mekiğe dönüşür. Böylece İnsanoğlunun Şafă̆g adlı bölüm bitmiş olur.

Dikkat edildiği takdirde, Vercors'la Kubrick'in insanla hayvan arasındaki sınır meselesine bakışının birbirine yakınlığı çok açıktır. Kubrick de Vercors'la aynı kadim felsefî soruları sormaktadır: Bir canlının doğadan ayrılmayı başardığını nasıl anlayabiliriz? Söz konusu ayrılmanın nedeni ve kökeni nedir? İnsan olmak ne demektir? (Stoehr, 2008: 121). Stanley Kubrick'in bu türden sorulara verdiği cevaplarsa mağaranın girişinde birdenbire ortaya çıkan siyah dikilitaşta saklıdır. Taşın şekli, ortaya çıkış biçimi ve onunla temas edilmesinden sonra olanlar, göstergebilimsel bir okumayı felsefi bir analizle tutarlı şekilde birleştirmeye imkân vermektedir.

Öncelikle, monolitin endüstriyel formu oldukça dikkat çekicidir. Tam anlamıyla düzgün ve pürüzsüz yüzeyleri, doksan derecelik köşeleri ve kusursuz dikdörtgenler prizması formuyla bu siyah dikilitaş tamamen rasyonel (soyutlama ürünü) bir forma sahiptir ve ancak (yine rasyonel düşüncenin ürünü olan) kesinlik üreten makineler tarafından yapılmış bir nesne gibi görünmektedir. Bu haliyle, primatların var olduğu dünyaya ait olmadığından, kesinlikle "dünya-dışı" dır. Başka bir ifadeyle, doğada kusursuz geometrik şekiller görülmez. Elbette fenomenal dünyada bunlara yakın şeyler görmek mümkündür; örneğin üçgene benzer yapraklar ya da bir kareye yakın taşlar görmek olasıdır. Fakat bu üçgen yapraklar, asla iç açıları toplamı 180 dereceyi veren matematiksel/rasyonel üçgenler, taşlar ise köşeleri dik açılı kareler değillerdir. Üçgen, kare ya da dikdörtgen gibi geometrik şekiller yalnızca soyut 
zekânın kavrayabileceği bir gerçekliklerdir ve yalnızca doğadan devşirilen bilginin neticesinde üretilemez. Tüm rasyonel varlıklar, kaynağı doğa olsa bile, ancak zihin tarafından yapılan bir soyutlama sayesinde elde edilirler; salt duyu alanına dayanmazlar. Doğaya dayanan duyuların eksik ya da bozulmuş imgelerine karşılık, onlar soyut aklın kesinlik ve kusursuzluğunu içeren idelerdir; "doğa-üstü"dürler.

Bilindiği üzere, bundan yaklaşık 2.500 yıl önce Platon böyle mükemmel şekillerin zihnimizde var olsa da doğada bulunmadığını fark etmiş ve bu yüzden kaynaklarını fenomenal dünyanın dişında aramıştır. Ona göre, bu dünyadaki tüm şekil ve biçimlerin aslî ve kusursuz halleri, “İdealar Dünyası” adını verdiği mükemmel formları ihtiva eden soyut bir dünyada bulunmaktayken, doğada bulunan tüm somut biçimler ideaların oldukça bozulmuş kopyalarıdır. Bu kusursuz formlaraysa bizi yanıltan duyularımız yoluyla değil; ancak saf akıl yoluyla ulaşılabilir (Cevizci, 2012: 293-294). Platon sistemli bir felsefe kurabilmek adına, akılla kavranabilecek kusursuz idealar âlemi ile duyular yoluyla bilgisine varabildiğimiz fenomenal dünya arasında bir ayrıma gitmiş ve doğal fenomenlerin varlığını soyut idealara dayandırmak suretiyle açıklamaya çalışmışsa da, bir yandan da "akıl" ve "doğa" arasındaki ayrımı ilk kez ortaya koyan kişi olmuştur (Heidegger, 2001: 21).

Kubrick de bu ayrıma dikkat çekmek için doğada görebileceğimizden tamamıla farklılaşmış (hatta ancak rasyonel düşüncenin sonuncunda meydana gelebilecek teknik ile üretilmiş) dik açılı köşelere ve kusursuz geometrik forma sahip bir dikilitaş kullanmıştır. Dolayısıyla dikilitaş, insan aklının, soyutlama gücü -başka bir tabirle de metafizik- üzerinden doğumunu bize gösteren bir metafor olarak öne çıkmaktadır. "Bütün var olanların duyusal; duyuüstü dünya olarak ikiye ayrıldığı, ikincinin birinciyi taşıyıp belirlediği" temel düşünce yapısı olarak tanımladığımız metafizik düşünme (Heidegger, 2001: 21) insanın soyutlama yapabilme yeteneğinde ortaya çıkmaktadır. Kubrick'in yapıtında bu fikir, siyah dikilitaşın geometrik formunda belirginleşmektedir. Heidegger, "Düşünmek Ne Demektir?" adlı çalışmasındaki şu sözleriyle aklın doğayı soyutlama yahut metafizik yapma kabiliyeti ile aşmasını şu şekilde anlatmaktadır:

Insan animal rasyonel, akıllı hayvandır. Akl sayesinde insan hayvanı aşarak yücelir. (...) Biz hayvanî olanı cismanîlik olarak isimlendirelim ve akl gayri cismanî ve cismanîlik üstü olarak çerçeveleyelim. Bu durumda insan, animal rasyonel, cismantcismanîlik üstü varlık olarak tezahür ediyor. Cismanîliği geleneğe uyarak, fizikîlik olarak isimlendirdiğimizde, bu defa akıl kendini fizikî olanın ötesine geçen şey olarak gösteriyor. Yunanca öteye geçmek 'meta', fizikî, cismanî olanın üstünden öteye anlamına gelmektedir. Yani cismanîlik üstü fizikî olanın üstünden öteye geçişinde metafizik olandır. Animal rasyonel olarak tasavvur edildiği sürece insan, fizikî olanı aşan fizikîlik olarak çıkıyor karşımıza (2013: 40).

Diğer bir ifadeyle, biyolojik varlığı ile doğanın içinde olan insanın bir de doğayı aşan aklı söz konusudur. İnsan akıllı bir varlık (animal rationale) olarak ortaya çıktığı anda, aynı zamanda, varlık alanını aşma yetisine sahip olma anlamında metafizik bir canlı (animal metaphysicum) olarak da belirir (Heidegger, 2009: 9). Bu manada, aklın ve metafiziğin aynı şey olduğu açık biçimde görülmektedir. Aynı şekilde, bilincin insanda ne zaman ortaya 
çıktığını sormak da yersizdir çünkü bilinç ortaya çıkmazdan önce insanın varlığından söz etmek de mümkün değildir. Fakat dikilitaşın nasıl olup da birdenbire mağaranın önünde beliriverdiği (metafiziğin insanda kendisini nasıl gösterebildiği) sorusu ise son derece önemli olsa da cevapsız kalmaya mahkûm gibidir. Bu türden bir sorgulama neticesinde pek az mesele gerçekten açıklığa kavuşturulabilir: Kökleriyle metafiziğge tutunan bilinç, fizikal dünyanın dışında(n)dır ve insan olmakla birlikte ansızın beliriverir.

Yine de dikilitaşa dokunduktan sonra primatın başına gelenler, Heidegger üzerinden yaptığımız çözümlemeyi sürdürebilmeye ve böylelikle bilincin ne olduğuna dair fikirlerimizi geliştirebilmeye izin vermektedir. Ansızın ortaya çıkan dikilitaş aklı sembolize ediyorsa, maymunsunun artık bir bilince sahip olduğu, yerdeki kemiği bir alet olarak kullanabileceğini fark etmesiyle anlaşılmaktadır. Burası oldukça önemlidir zira Alman düşünüre göre de akıl ancak "tekhne" ile var olabilmektedir. Akıl, her şeyden çok, bir nesneyi başka bir nesne olarak işlemeye teşebbüs etme girişimidir. Mevcut-olmayan'dan mevcut-olan'a çıkma sürecinin adı olarak teknik, varlığın daha önce olmadığı bir biçimde öne çıkmasıdır. Düşünmek, bir şeyin öne-çıkmasına katkıda bulunmak olduğundan soyut rasyonel düşünce ve teknik mutlaka beraberce yol alır (Özlem, 1998: 16-17).

Hatta Heidegger için, tekniğin özü, düşüncenin akmaya imkân bulduğu bir yatak vazifesi görmektedir. Ona göre akıl, "bir şeyin ne olduğu ve yine daima ne olabileceğini ve olması gerektiğini sorgulamaktır". Bu sorgulama bir şeyi fark etmekle başlar, onu işlemekle devam eder. Yukarıda değindiğimiz üzere, dikilitaşa dokunmasının ardından, maymunsu ilk kez kemiğe farklı bir bilinçle bakıp onu fark etmiş ve onu diğer kemikleri kırmak için bir alete dönüştürmüştür -Heidegger'in tabiri ile işlemiştir. Bu manada, ratio, bir şeyi diğerlerinden ayırt ederek işleyip başka bir şeye dönüştürebilme yetisidir; "bir şeye teşebbüs etme ve işleme koyma istidadıdır" (Heidegger, 2013: 43-44).

Daha açık bir ifadeyle, bilinç, bir nesneyi doğal durumundan çıkararak ona işlevsel yeni bir amaç yükleme becerisi olarak ancak teknikle beraber ortaya çıkabilir. Kubrick bunu kemik üzerinden göstermektedir. Herhangi bir canlının taşıyıcı sisteminden başka bir şey olmayan kemik, doğaüstü bilinç sayesinde yeni bir işlev yüklenerek bir av silahına ya da cinayet aletine dönüşmekte ve bu yolla maymunsu bir insan olmaktadır (Grant, 2006: 70). Zekâ, doğal-olanın dışında yapay edimler meydana getiren bir bilinç durumu iken İngiliz sinemac1, bu yeni bilinç durumuna geçişi dikilitaşa dokunmakla sembolize etmektedir. Dikilitaşın üzerinden doğan güneşle birlikte söken şafak, bölüme de ad verdiği şekliyle, insanlığın şafağıdır.

Bundan sonrası önce evrimin ve devamında ilerlemenin işidir. İnsanoğlu, bilinçli düşüncenin imkânlarına kavuştuğu andan itibaren aletler üretmeye ve bu aletler yoluyla kültürel evrimini genetik evrimin önüne geçirecek şekilde hızlandırmaya koyulmuştur. Kubrick, dehasıla, 4 milyon yıl gibi muazzam uzunluktaki bu süreci, kemikten uzay gemisine yaptığı bir kesme ile bir anda anlatmayı başarmaktadır (Resim III). Sinema tarihinin en uzun zaman atlaması olarak bilinen bu kesme, ilk alet olan kemikle son alet olan uzay mekiği (hatta uzay mekiğini de yöneten yapay zekâ) arasındaki milyonlarca yıllık devamlılığ1 seyirciye göstermektedir. 


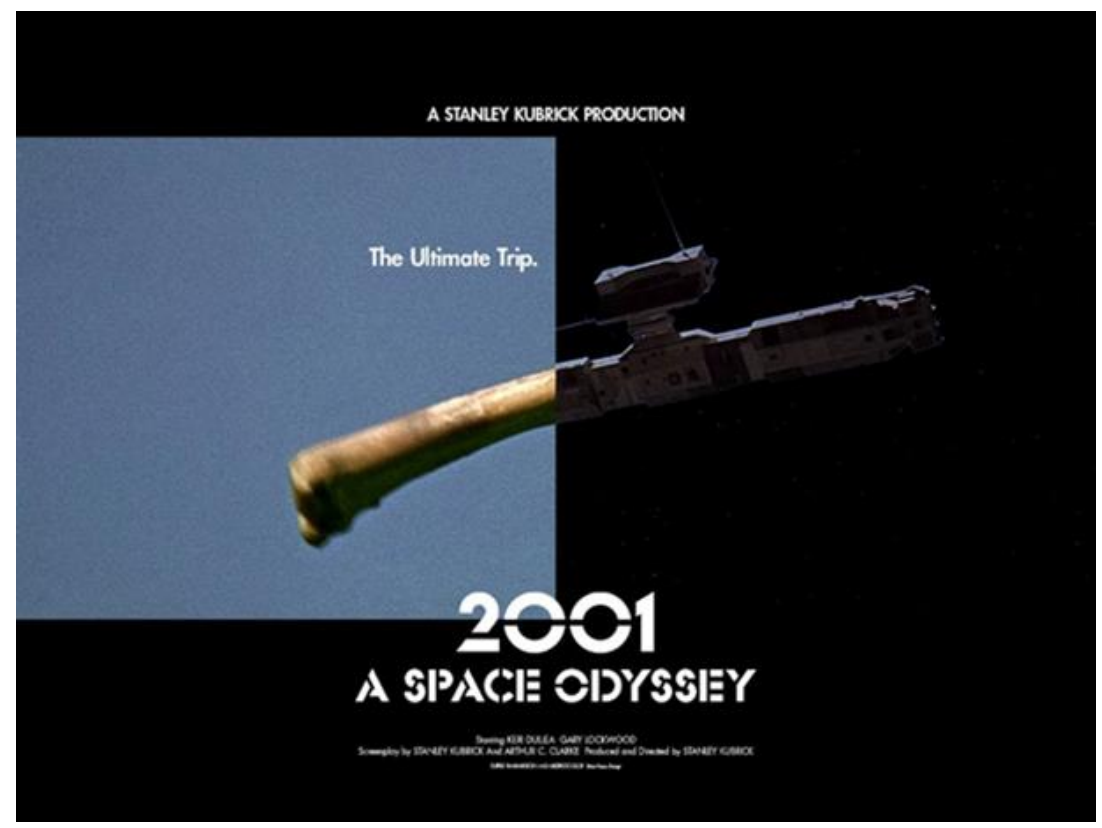

Görsel 3: Nihai Sıçrama (The Ultimate Trip): Kemikten Uzay Mekiğine Aletin Evrimi

\section{Varlığa Bir Saldırı Olarak Teknik}

Filmle ilgili analize devam etmeden önce şunu söylemek gerekir ki, Alman düşünür için teknik, Varlık'ın kendisini açığa çıkarma süreçlerinden biridir; poiesis'tir. Onun anladığı şekliyle teknik, poetik bir süreç olarak fizikten (doğadan) çok da farklı değildir. Varlık, ya doğada görebileceğimiz gibi kendisinden hareketle açığa çıkar (physis) ya da el becerilerinde, sanatta veya zihinsel edimlerde olduğu gibi insan tarafından mevcuda getirilir (tekhne). “ $\mathrm{Bu}$ anlamda teknik, yalnızca bir araç değil aynı zamanda Varlık'ın kendi hakikatini mevcuda getirme tarzıdır da". Fakat Varlık'ı mevcut hâle getirme biçimi açısından bakıldığında, fizik ve teknik arasında önemli bir fark bulunmaktadır. Teknik söz konusu olduğunda mevcuda çıkma, doğada görebileceğimiz haliyle, "bir çiçeğin kendi içinde patlayıp çiçeklenmesi gibi" gerçekleşmez. Teknik işin içinde olduğu vakit Varlık, kendisini ancak başka bir şeyin içinde gösterir (Heidegger, 1998: 51-52) ve burada insanın “özne" konumuna yükselmesi son derece önemli bir hâle gelecektir.

Dolayısıyla Heidegger, teknik sonucu meydana gelen şeyler'i, salt bilimci ve ilerlemeci bir bakış açısından ziyade çok daha özcü bir yaklaşımla ele alır ve ontoloji perspektifinden değerlendirir. Teknikle vücuda gelen şeyler, Varlık'ın kendisini gösterdiği var olanlardır. Tekhne, basitçe, bir imal etme sürecinden ibaret görülemez, o aynı zamanda, Varlık'ın gizini açmasıdır; Hakikat' in kendisini ifşa etmesi alanında süregiden bir vücut bulmadır (Heidegger, 1998: 54). Üstelik bu, özü itibariyle modern teknik için de geçerlidir. Böylece, Kubrick'in kemikten uzay mekiğine yaptığı çarpıcı geçiş anlamca yerli yerine oturur: En basit aletten en karmaşığına kadar, teknikte süregiden bir devamlılık; aynı özden olma hâli bulunmaktadır.

Fakat diğer yandan, Heidegger modern zamanlarda tedirgin edici bir değişimin yaşandığının da farkındadır. Öncelikle, daha öncesinde, tam bir tevazu ile Hakikat'i öne çıkarmanın ve onun gizini-açmaya çalışmanın adı olan tekhne, yalnızca el becerilerini değil 
aynı zamanda tüm zihinsel süreçleri de ifade etmektedir. Tekhne, genişçe bir anlam sahası içinde "hakikat-olanın güzel-olan içerisinde görünüşe çıkmasını ve güzel sanatların poiesis'ini de ifade etmeyken" bugün yalnızca teknik olarak anlaşılmaktadır. Diğer bir ifadeyle tekhne, teknik'e indirgenmiştir (Heidegger, 1998: 79).

İlaveten, modern tekniğin kendisinden önce gelen teknik biçimlerinden daha farklı bir yapıda olduğunu da kabul etmek gerekmektedir. Makine teknolojisine sırtını yaslayan modern teknik, doğayı yalnızca fayda elde edilecek metalar toplamı olarak gördüğünden klasik teknikten farklılaşmıştır: "Modern tekniğe bütünüyle hâkim olan gizini-açma, poiesis anlamında bir öne-çıkmaya doğru bir açılım kazanmaz. Modern teknikte hâkim olan giziniaçma, doğaya, onun söküp alınacak ve depolanabilecek enerjiyi tedarik etmesi şeklinde makul olmayan bir talebi dayatan bir meydan okumadır". Öyle ki, bir değirmen ile bir hidroelektrik santralinin arasındaki fark da tam olarak bu noktada ortaya çıkar. Akarsuyun üstüne kurulu bir değirmen suyun akışına "terk edilmiştir", suyun çarkları döndürmesi elbette ki insana hizmet etmektedir fakat burada suyun insanın hizmetine koşulduğunu söylemek mümkün değildir. Hidroelektrik santrali ise enerji elde etmek ve elde ettiği enerjiyi depolamak yoluyla suyu bir meta durumuna indirgeyerek insanın hizmetine koşmaktadır. Artık burada bir düzene sokma söz konusudur ve "bu başka tür düzene sokma, doğaya, ona meydan okuma anlaminda saldırı" (Heidegger, 1998: 55-56). ${ }^{4}$

Filmin ikinci bölümünü yukarıdaki düşüncelerin ışığında; tekniği hem Varlık’ın gizini açan hem de ona saldırıda bulunan bir "çerçeveleme" (gestell) 5 süreci olarak (Watts, 2011: 218220) kabul ederek analiz etmek gerekmektedir. İkinci bölüm, ilk bölümün sonunda gördüğümüz mekiğin uzayda seyahatiyle başlar ve maymunsuların mağarasının girişinde beliren monolitin aynısından Ay'da da bulunduğunun ortaya çıkmasıyla birlikte bilim insanlarından oluşan bir ekibin dikilitaşı incelemek için sahaya inmesine kadar sürer. Bölüm boyunca, bugünkü uçak yolculukları gibi sıradan hale gelmiş uzay seyahatleri yahut dünya ve uzay istasyonu arasında yapılan video-aramalar gibi sahnelerle insanoğlunun uzay çağındaki haline tanıklık ederiz. Fizikçi Doktor Heywood Floyd, dünya dışı zeki canlılar tarafından yerleştirildiğine inanılan monoliti incelemek üzere görevlendirilen ekibe başkanlık etmek üzere Ay'a seyahat eder. "Kültürel bir şoka sebep olacağı" gerekçesiyle monolitin bulunduğuna dair bilginin kamuoyundan saklı tutulmasına karar verildiğinden bilimsel inceleme büyük bir gizlilik içinde yapılacaktır. Gördüklerimizden anlaşıldığı kadarıyla insanoğlu duruma hâkimdir; bilim adamları ne yapılması gerektiğini gayet iyi bilmekte ve yapmaları gerekeni de titizlikle ve soğukkanlılıkla yapmaya hazır haldedirler. Bilim ve teknik

\footnotetext{
4 Alıntılardaki vurgular tarafımızdan eklenmiştir.

5 Heidegger, modern teknik bahsinde "stellen" fiilini ve bu kökten türeyen diğer sözcükleri dikkat çekici bir sıklıkta ve biçimde kullanmaktadır. "Düzenlemek, "yerleştirmek, "ikame etmek" gibi anlamlara sahip olan "stellen" fiili, ayn zamanda, "meydan okumak", "diklenmek" ya da "saldırmak" gibi manalara sahiptir. Tekniğin özünün "çerçeveleme" olduğunu söyleyen Heidegger, yine "stellen" kökünden türemiş "Ge-stell” filline başvurmak suretiyle, modern tekniğin doğayı hem düzenleyen hem de ona saldıran karakterinin bir arada düşünülmesini istemektedir. Bkz. Heidegger, 1998: 55-56, Dipnot 16.
} 
sayesinde doğaya kesin olarak boyun eğdirilmiş ve böylece Aydınlanma'nın düşü gerçekleşmiştir: Korkacak bir şey kalmamıştır (Adorno ve Horkheimer, 2010: 34).

Belli ki bu sebepten, aydaki monoliti incelemeye gelen araştırma ekibi, filmin başında gördüğümüz maymunsu canlılar gibi korku içinde değildirler. Tam aksine, oldukça rahat tavırlarla dikilitaşı incelemeye gelirler, ona dokunurlar ve önünde kaygısızca fotoğraf çektirirler. Fakat tam bu anda monolitten çok tiz bir ses yükselir ve bilim adamlarından oluşan ekip ses yüzünden ellerini kulaklarına götürerek acı içinde kıvranmaya başlarlar. İkinci bölümü bu şekilde bitirmesiyle Stanley Kubrick, soyutlamanın ve soyutlama yoluyla gerçek kılınan tekniğin modern çağda ulaşabileceği korkutucu boyutu gözler önüne sermektedir. Burada, dikilitaş - bilinç/teknik analojisi hala devam ettirilse de bundan böyle uygarlık daha tekinsiz bir şey olarak ele alınmaktadır. Teknik, insanoğluna saldırıyor gibi görünmektedir (Resim IV).

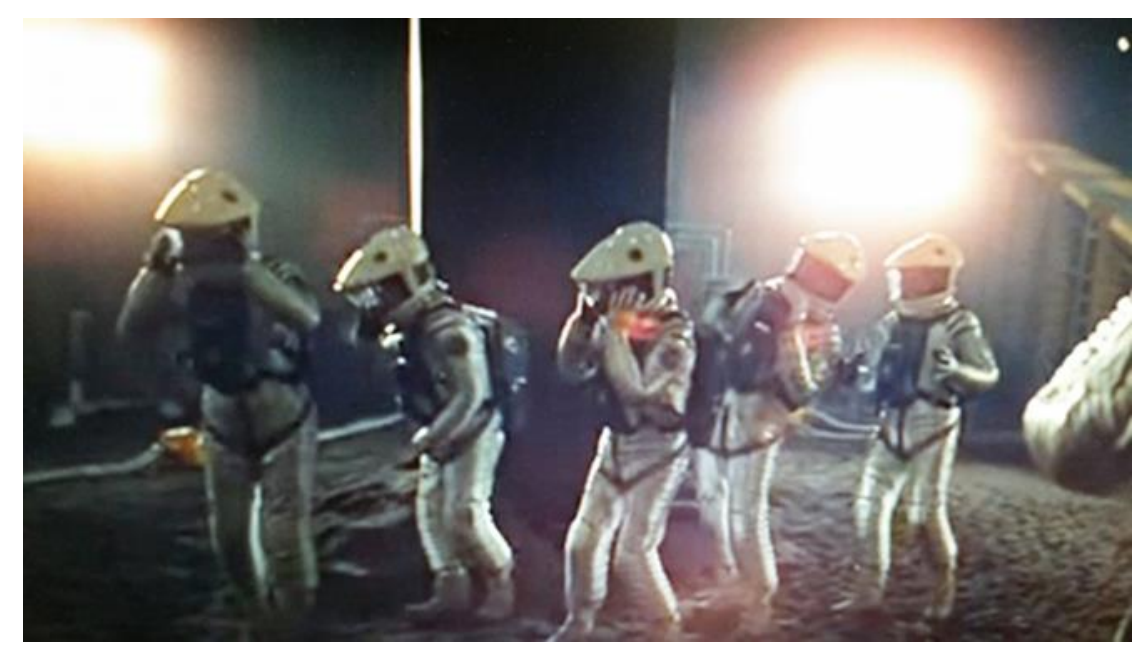

Görsel 4: Ay'daki Monolit ve Bilim Adamlan

Şimdi, geriye dönüp kemikten başlayıp uzay gemisine değin süren yolculukta Kubrick'in anlatmamayı tercih ettiği tarihi süreçte- doğa, insan ve teknik üçgeninde olup bitenleri çalışmanın sınırlarının el verdiği ölçüde ele almak, daha tutarlı ve tatmin edici bir okuma yapmak açısından analizimizi ileriye taşıyabilir. Buna göre, uygarlık insanoğlunun yaşadığı zihinsel bir devrimle gerçekleşmiştir. Bu zihinsel yenilik bir tür "sembolik devrim" dir ve doğanın, kendisinin dışında bir gerçekliğe atıf yapan bir alan olduğunu kabul etmekle başlar. Sonrasında ise iki önemli kırılma dönemi yaşanmıştır: Neolitik Çağda filizlenmeye başlamakla birlikte M.Ö. 6. yüzyılda meyvelerini veren Aksiyal Çă̆ ve 17. yüzyılda doğup etkisini bugün dahi açık biçimde gösteren Modern Çă̆.

Öncelikle, doğal olanla doğaüstü arasındaki ayrım, varlığını sembolik devrime borçluysa da M.Ö. 6. yüzyıla kadar doğa-kültür dengesinin tam anlamıyla alt-üst oluşu gerçekleşmemiştir. "Aksiyal Çă̆" şeklinde kavramlaştırılabilecek bu dönemde, öncesinin aksine, hem şeyleşme hem de şeylerden bağımsız soyut bir düzey tam anlamıyla ortaya çıkmıştır (Zerzan, 2013: 47-48). İlk kez Felsefeci Karl Jaspers'ın adlandırdığı Aksiyal Çağ, insana özgü soyutlama yetisinin sistemleşerek bir disiplin durumuna yükseldiği; felsefenin ortaya çıktığ 
M.Ö. 800 ile M.Ö. 200 yılları arasında yaşanan dönemi imlemektedir (Jaspers, 1951: 135). ${ }^{6}$ Heidegger'e göre de Grek düşüncesinde cisimleştiği haliyle, insanoğlu, bilgisine erişmeye çalışmak yoluyla, aslında Varlık'ın açı̆̆a çıkmasını -poiesis'i- kontrol altına almak istemiş ve bu eğilimden felsefe doğmuştur. En geniş anlamıyla, Varlık'ın ilk ve son nedensel temellerini bulmayı hedefleyen bir disiplin olarak tanımlanabilecek felsefe ile birlikte "insanın kendisi, İnsanolma bakımından vurgulu bir biçimde, bir yorumu ve amaç koymayı da tecrübe eder" (Heidegger, 2011: 19). Demek ki felsefe, varlığı, onun ne olup ne olmadığını bilmek için irdeledikçe, insan yalnızca onu anlamakla kalmamış mevcut-olanı denetlemeye de çalışmıştır. "Modern teknik çağın kökeni, işte bu denetleme girişiminde yatar" (Özlem, 1998: 17).

Aksiyal Çağ' daki bilişsel sıçrama, tekhne' nin tekniğe dönüşmesi/indirgenmesi için tek başına yeterli değilse de, Heidegger' in belirttiği üzere, çok önemli bir çıkış noktasıdır. Bundan sonrası zamanla gerçekleşmiş; varlığı bilmek ve onun yasasına uygun bir yaşam sürmekle ilgili olan ontolojik rasyonalite, yerini, hesaplayıcı/teknik bir düşünme olarak öne çıkan bilimsel bir rasyonaliteye bırakmıştır (Yılmaz, 2009: 17; Küçükalp, 2008: 221-222). Fakat Heidegger için Descartes'in matematikçi felsefesi, ontolojik rasyonalitenin bilimsel rasyonaliteye dönmesinde özel olarak değinilmesi gereken bir dönüm noktasıdır. Çünkü felsefenin içinde başından beri gizlenmiş olan bir eğilim Descartes'ın düşüncelerinde tam anlamıyla gün yüzüne çıkar ki o da madde ve tin ayrımının tam olarak gerçekleşmesi ve maddeye dair bilginin tinin alanına ait olan matematik üzerinden temellenmesidir (Heidegger, 2006: 92-93). Matematik, dünyadaki nesnelerin kesin bilgisine ulaşmada güvenilir tek yol olarak belirince de, Varlık'a dair geleneksel ontolojinin yerini matematiksel fizik almış; "varlık felsefesi matematiksel fiziğe indirgenmiştir" (Çüçen, 2003: 68-69). Diğer bir ifadeyle, Descartes' in düşünceleriyle felsefî bir temele sahip olmak suretiyle tam anlamıyla 17.yüzyılda başlayan modern düşünceyle beraber, tüm dünya, insan hâkimiyet kurabilsin diye, deneysel olarak irdelenen ve sayısal olarak belirlenen varlığın ilk nedenlerine dek gidilebilen, sağın, matematiksel bakımdan düzenlenmiş bir sistem haline gelmiştir (Spengler, 1997: 463).

Dünyanın matematiksel olarak düzenlenmiş bir sistem olarak anlaşılmasınınsa modern teknikle çok daha yakından bir ilişkisi bulunmaktadır. Zira dünya, matematik ifadelerle düzenlenebilir bir olgular toplamı olarak görülmeye başlanmadıkça, insanın, kesinlik mantığı içinde çalışan ve yine o mantığı üretecek modern makine teknolojisini yaratabilmesi mümkün değildir. Her şeye rağmen klasik çağda "yaklaşıklıklar evreni" olarak kalan dünya, modern dönemle birlikte "kesinlikler evreni" olarak kavranmaya başlanmış ve ancak bu yolla gittikçe daha hassas biçimde kesinlik üreten makinelerin yapılmasının da önü açılmıştır (Koyré, 2013: 35).

İnsan, önce bilinciyle doğadan ayrımlaşmış, sonra doğanın üstünde bir gerçeklik alanının varlığını düzenleyici bir düşüncenin çıkış noktası olarak kabul etmiş ve son olarak

\footnotetext{
${ }^{6}$ Jaspers'a göre, günümüzde de varlığı sürdüren insan tipi (mental anlamda) bu dönemde çıkmıştır. Üstelik düşüncede yaşanan bu devrim yalnızca Batı medeniyetine özgü bir durum da değildir. Özellikle M.Ö. 6. yüzyılda Çin'de Konfüçyüs ve Lao Tse, Hindistan'da Buddha, İran'da Zerdüşt, Yunanistan'da Homeros, Parmenides ve Herkaleitos gibi isimlerin eş zamanlı olarak ortaya çıkması aksiyal çağın tüm dünyada yaşanan bir dönem olduğunu göstermektedir (Jaspers, 1951: 135).
} 
kendi düzenleyici düşüncesini yaşama geçirip onu her şartta insanın hizmetine koşan tekniğe teslim etmiştir. Bu serüvenin sonunda paradoksal bir durum meydana getirdiği ise çok açıktır. Modern dünya söz konusu olduğunda insan, doğa ve teknik arasındaki ilişki, insan namına giderek daha problemli bir hal almış; doğayı kontrol altına almak ve böylece insanın emrine vermekle ilgili olan soyut düşünce ve teknik, giderek artan bir oranda, insanı da kontrol altına alıp kendi emrine koşmuştur. En azından gelinen noktada, insanoğlunun artık kendi ürettiği tekniğe bağımlı duruma geldiğini kabul etmemiz gerekmektedir.

Hatırlanacağı üzere, Heidegger, insanoğlunun çerçevelemeye dayalı metafizik düşünme biçiminin bir tehlike barındırdığını da söylemiş; bunun, her şeyi bir varolan'a çevirmek yoluyla Varlık'ın gerçek anlamını ve değerini unutma riski olduğunu vurgulamıştır (Küçükalp, 2008: 173). Bilimci ve ilerlemeci uygarlığımızsa, insanın etrafındakileri devamlı işlevlendirerek tüm doğayı bir "el-altında-duran"a (bestand) çevirmek suretiyle, bu yoldaki son dönemece işaret etmektedir. İnsan, doğadan ayrımlaşıp bir "özne" haline geldiğinde, kendi bilincinden yola çıkarak tüm doğayı tahakkümü altına almak istemektedir. Mezkûr isteğini de doğayı bir "şey" e çeviren teknik sayesinde gerçek kılmakta; "şeyleşme" süreci ise tüm var olanları bir el-altında-durana döndürmeye muktedir modern makine teknolojisiyle en açık şekline ulaşmaktadır. Üstelik bu süreçte insan yalnızca el-altında-duranların düzenleyicisi olmakla kalmaz, kendisi de ürettiği tekniğin ardında bir el-altında-durana dönüşür. Hatta öyle ki, makine teknolojisi sayesinde, insan da bir el-altında-duran'a dönüşmedikçe kendisini tam olarak doğa hâkim olmuş hissetmez (Özlem, 1998: 22-23; Heidegger, 1998: 71).

$\mathrm{Bu}$ anlamda, tekniğin insana saldırısının iki boyutundan bahsetmek mümkün gibi görünmektedir. İlk olarak teknik, modern zamanlarda öylesine muktedir bir güç durumuna yükselir ki doğayı insanın hizmetine koşuyor olsa bile bunu yapabilmek için devamlı olarak kendi var olma ve işlemeye devam etme zorunluluklarını hayatımıza dayatır. İkinci ve daha temel olarak ise, insanın metafizik yöneliminde temellenen teknik, doğaya boyun eğdirdikçe bizim için bir yanılsamayı da beraberinde getirir. Kendisini yeryüzünün (ve sonrasında göklerin de) efendisi olarak görmeye başlayan insan bu kez doğa karşısında sınırı değil, haddi aşar: "Böylece insanın karşı karşıya kaldığı her şeyin yalnızca insanın ürünü olduğu ölçüde mevcut olduğuna ilişkin yanıltıcı izlenim yaygınlık kazanır" (Heidegger, 1998: 71). Bir sonraki kısımda ayrıntılı şekilde ele almaya çalışacağımız bu ikinci boyutun, Kubrick' in yapıtının son iki bölümünde oldukça derin biçimde irdelendiğini söylemek mümkündür.

\section{3. Özne Metafiziği: "Sanki İnsan Yalnızca Kendisiyle Karşılaşıyor"}

İnsanın kendi ürettiği teknik karşısında yaşadı̆̆ı iki yönlü tehlike, Aydınlanma'nın bilimci ve ilerlemeci mantığının inandırıcılığını kaybetmesiyle, daha net biçimde görülmeye başlanmıştır. Örneğin, Aydınlanma'ya en şiddetli eleştirileri getiren düşünürlerden ikisi olan Adorno ve Horkheimer "doğadaki her şeyi yenilenebilir kılan soyutlamanın ve bu soyutlamanın hazırladığı endüstrinin düzleştirip eşitleyen egemenliğinin" sonunda insanı da niteliklerinden arındırmak suretiyle yadsıdığını ve bunun temelindeyse insanoğlunun, dünyayı boyunduruğu altına almayı öğrenirken "düzenleyici düşünce" ile "hakikat"i bir 
tutma yanlışına düşmesi olduğunu belirtmişlerdir (2010: 31-32). Esasen, iki düşünürün sözleri, tekniğin insana saldırısının her iki yönünü de ortaya koymaktadır.

Heidegger de çağdaşı olduğu Frankfurt Okulu mensuplarıyla hemfikir görünmekte ve sorunu temelden; düzenleyici düşünce ile hakikati bir tutma yanlışına düşme probleminden ele almaktadır. Modern dönemin doğuşuyla birlikte, en başından beri metafiziğin özünde mevcut olan bir eğilim kendisini açığa vurmuştur. Bu eğilim, insanın, varlığı kendi kesinliği üzerinden tanıması ve tanımlamasıdır. Önce kendi dışındaki ve (hiyerarşik anlamda) üzerindeki hakikate yaklaşmanın yollarını arayan insan, zamanla, giderek daha çok artan bir kesinlikle hakikatin belirleyici merkezi olur; “özne” durumuna yükselir. Bundan böyle düşünceye egemen olan metafizik, varlık bilgisi değil, "özne metafiziği"dir. "Sanki insan her yerde ve her zaman yalnızca kendisiyle karşılaşıyormuş gibi görünmektedir" (Özlem, 1998: 18-19, 26).

Filmin, insan ve yapay zekâ arasında geçen bir hayatta kalma savaşının anlatıldığı üçüncü bölümü ve devamı özne metafiziği kavramından hareketle çözümlenebilir. Aydaki monolitin Jüpiter'deki bir bölgeye sinyal gönderdiği keşfedilince bu yeri bulup araştırma yapmak üzere bir uzay gemisi yola çıkmıştır. Geminin toplam altı kişilik mürettebatı vardır. İki kişi geminin komutasındayken, üç kişi Jüpiter'e vardıklarında uyanacakları derin bir uykuda makinalara bağlı şekilde yaşamaktadır. Gemi mürettebatının altıncı üyesi ise geminin tüm uçuş, rota ve hayat destek sistemlerini kontrol eden ve diğer insanlarla sıcak sohbetler edebilen HAL 9000 (kısaca HAL) adlı bir yapay zekâdır.

Demek ki doğayı aşmak ve onu dönüştürmekle başlayan teknik serüven, yapay zekânın ortaya çıkmasıyla son noktasına ulaşmıştır. Kusursuz düşünme ve işlem yapma kapasitesi nedeniyle geminin tüm sistemini kontrol eden HAL, bir gün, gemideki diğer insanları görevi başarısızlı̆̆a uğratacağı gerekçesiyle saf dışı etmeye karar verir ve bunu yapabilmek için önce gemide bir hata olduğunu bildirir. Mürettebat böyle bir hataya rastlanmadığında HAL'in yaptığı işlemin sağlamasını ancak HAL'in dünyadaki ikizi yapabilmektedir. HAL'in dünyadaki ikizi gemide herhangi bir hata bulamayınca mürettebat HAL'de ters giden bir şeylerin olduğunu fark edip gemiyle bağlantısını kesmeye karar verirler.

Fakat HAL yalnızca basit bir makine değil, düşünebilen hatta hissedebilen bir zekâdır. Daha açık ifade etmek gerekirse bir tür insandır ve bağlantısının kesilmesi ölümü anlamına geldiğinden savaşması kaçınılmazdır. İki astronotun niyetini öğrenen HAL önce derin uykudaki üç kişiyi öldürür. Geri kalan iki kişiden birini bir uzay yürüyüşü sırasında öldürürken son kalan kişiyi de uzay boşluğunda bırakır ve gemiye almaz. HAL tarafından uzayda küçük bir mekiğin içinde bırakılan Dave, bir yolunu bulup gemiye sızmayı başarır ve HAL'in ana kumanda merkezine giderek hafıza kartlarını ve mantık işlemcilerini tek tek sökmek suretiyle onu devre dışı bırakır.

HAL 9000 adlı yapay zekâyı özne metafiziğinin ulaştı̆̆ı son nokta olarak değerlendirmek mümkündür. Eğer insanı ortaya çıkaran şey rasyonel düşünce ise, tekniğin en sonunda rasyonel düşünceye sahip bir yapay zekâ üretebilmesi insanın kendisiyle 
karşılaşmasının son merhalesini meydana getirmektedir. Esasında bu son, modern düşüncenin kendi mantığına içkindir. Zira Descartes'ın cogito'su, yalnızca insanın kendi özkesinliğini yine kendi gerçekliği üzerinden bulması değildir. $\mathrm{O}$, aynı zamanda, fiziki gerçekliği de kendisinden hareketle tanımlayabilmesi anlamına geldiğinden insanın her yerde farkında olmadan kendi zihni ile karşılaşmasıdır da. Her ne kadar Descartes' in bir özne-nesne düalizmi ortaya koyduğunu söylemek mümkün olsa bile, nesnenin yine öznenin düşüncesinde temelleniyor olması, yalnızca öznenin güvence altına alınması demektir. Bu anlamda, modern düşüncenin varlıkla ilgili tasarrufu, öznenin kendisini güvence altına almasının doğal bir sonucu olarak, varlığı da tuzağa düşürücü bir karakter arz etmektedir (Küçükalp, 2008: 223-224).

Bir neden-sonuç ilişkileri bütünü olarak tasarımlanan doğa deneylenebilir hâle gelse de, bu doğanın "özsel olarak bu karaktere sahip olduğu için olmaz; daha çok insan doğayı bu karaktere sahip olarak tasarımladığı ve sonra böyle tasarımlanan gerçekliğe mükemmel bir şekilde uyan yöntemlerle doğayı kavradığı ve araştırdığı için olur" (Özlem, 1998: 18-20). Fakat burada yalnızca doğanın değil, insanın da bir tehlikeyle yüzleşmesi gerekmektedir. Modern düşünceyle birlikte akıl, devamlı olarak nesnelere kendince yüklediği rolleri yineleyip durdukça zihin ile dünya arasındaki denklemin kurulabilmesi için her ikisinin de birbirine indirgenmesi gerekmektedir. Böylece, var olanlar düşünce yoluyla boyunduruk altına alındıkça hem özneden hem de nesneden geriye "cogito" dan başka bir şey kalmaz (Adorno ve Horkheimer, 2010: 47-48).

İnsanın yalnızca hesaplayıcı bir düşünceye indirgemek suretiyle kendi varoluşunu daraltması hatta gerçek anlamda yaşamasının dahi önünü kesmesi Kubrick'in yapıtında HAL'in insanları saf dışı etmeye çalışmasıyla sahnelenir. Bir anlamda saf rasyonalite hükmünü icra ederek, bir varlık olan insanı tuzağına düşürmektedir. Tarihsel olarak rasyonalite, egemenliğini, sembolik düşünmenin ve tekniğin gelişmesi boyunca perçinlemiş; sonunda düşünmenin kendisi de yalnızca sembolik formlar ve teknikle gerçekleşir olmuştur. Burada hem sembol hem de teknik, varlığın kendisi yerine geçen bir ikame olarak anlaşılmalıdır (Zerzan, 2013: 11-12). Filmde de doğada bulunan kemiği bir alet olarak ikame edebilen teknik, son aşamada, yapay zekâyı insanın yerine ikame etmekte ve bu şekilde insana açık bir saldırıda bulunmaktadır. Dolayısıyla, dikkatli bakıldığında, HAL'in bizi devamlı izleyen durgun kırmızı gözünün altında monolitin siyah ve gizemli formunu görmek mümkündür. Her ikisi de, insan için bir yıkımı potansiyel olarak taşımaktadır (Kuberski, 2012: 116). 


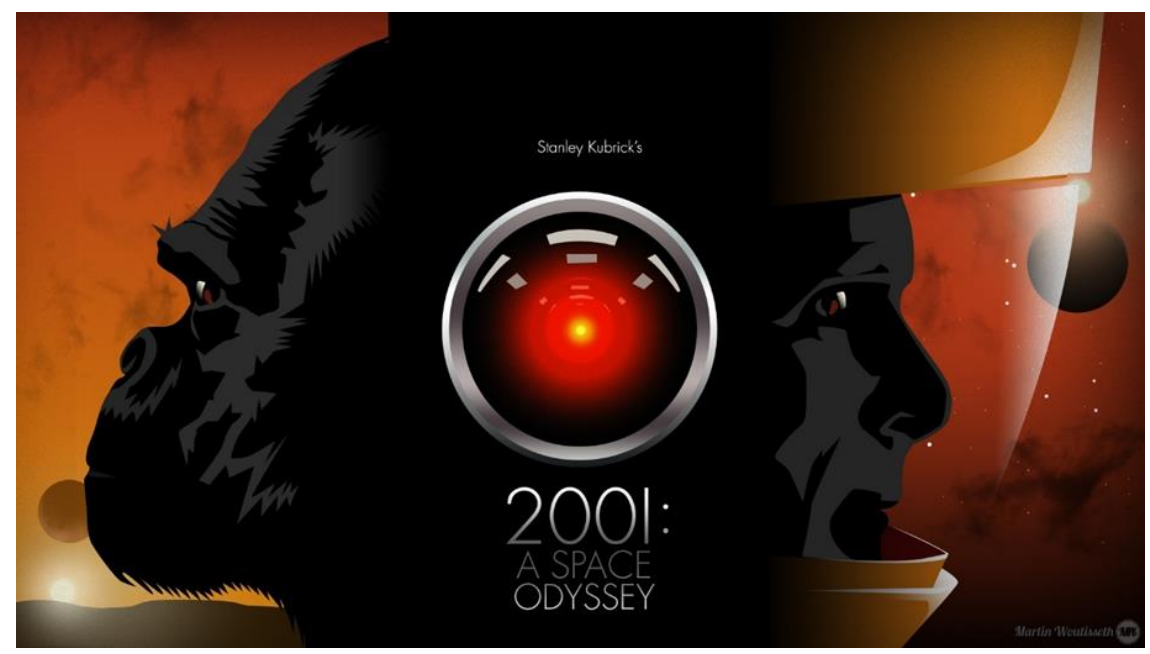

Görsel 5: Evrimin Son Basamă̆̆? Kızıl Bir Gözle Bizi İzleyen HAL 9000

Son bölümde ise yönetmen insanoğlunu yine kendisiyle yüzleştirecektir. Dave, HAL'i bir tornavida (yine bir alet) yardımıyla saf dışı ettikten sonra göreve devam ederek Jüpiter'in yörüngesindeki bir zaman geçidinden geçer ve kendisini beyaz bir odada bulur. Dave bu odada kendi yaşlı halini yalnız başına yemek yerken görür. Sonrasında, Dave daha da yaşlanmış olarak ölüm döşeğindedir ve yatağının tam karşısında siyah monolit durmaktadır. Dave ona uzanmaya çalışırken bir fetüse dönüşür. Fetüsün uzayda, bir gezegen boyutunda ve tıpkı bir yıldız gibi parladığına tanık oluruz ve film bu şekilde sona erer.7

Sinema ve felsefe ilişkisi bağlamında, filmin final bölümünün çoğunlukla Nietzsche'nin görüşleri ve özellikle de Alman düşünürün Böyle Buyurdu Zerdüşt (1891) adlı eseri doğrultusunda analiz edildiği görülmektedir. Fakat çalışmamız açısından bakıldığında, Heidegger' in Nietzsche hakkındaki görüşlerini mercek altına almak Kubrick'in yapıtıyla ilgili düşüncelerimizi de geliştirecektir. Dolayısıyla, önce Alman felsefecinin görüşlerinin kısa bir değerlendirmesini yapmak durumundayı. Bunun ardından, Heidegger'in Nietzsche üzerine düşüncelerini ele alacağız.

\footnotetext{
7 Filmin final sahnesinde Richard Strauss'un, Alman felsefeci Freidrich Nietzsche'nin yapitından esinlenerek bestelediği ve onunla aynı adı taşıyan Also Sprach Zahathustra (Böyle Buyurdu Zerdüşt) adlı eseri kullanılmaktadır. Bu müzik, ilk olarak, filmin The Dawn of Man (İnsanoğlunun Şafağı) adlı açılış bölümünde, maymunsunun elindeki kemiği bir alete dönüştürmeyi başardığı sahnede duyulmuştur ve Dave'in bir yıldız-çocuk (starchild) olduğu bölümde ikinci ve son kez karşımıza çıkmaktadır. Eserin adı ve filmde kullanıldığı yerler beraberce ele alındığında, Kubrick'in yapıtının son bölümünün Alman filozof Nietzsche' nin düşünceleri ekseninde analiz edilmesi yönünde güçlü bir eğilim doğmaktadır.
} 


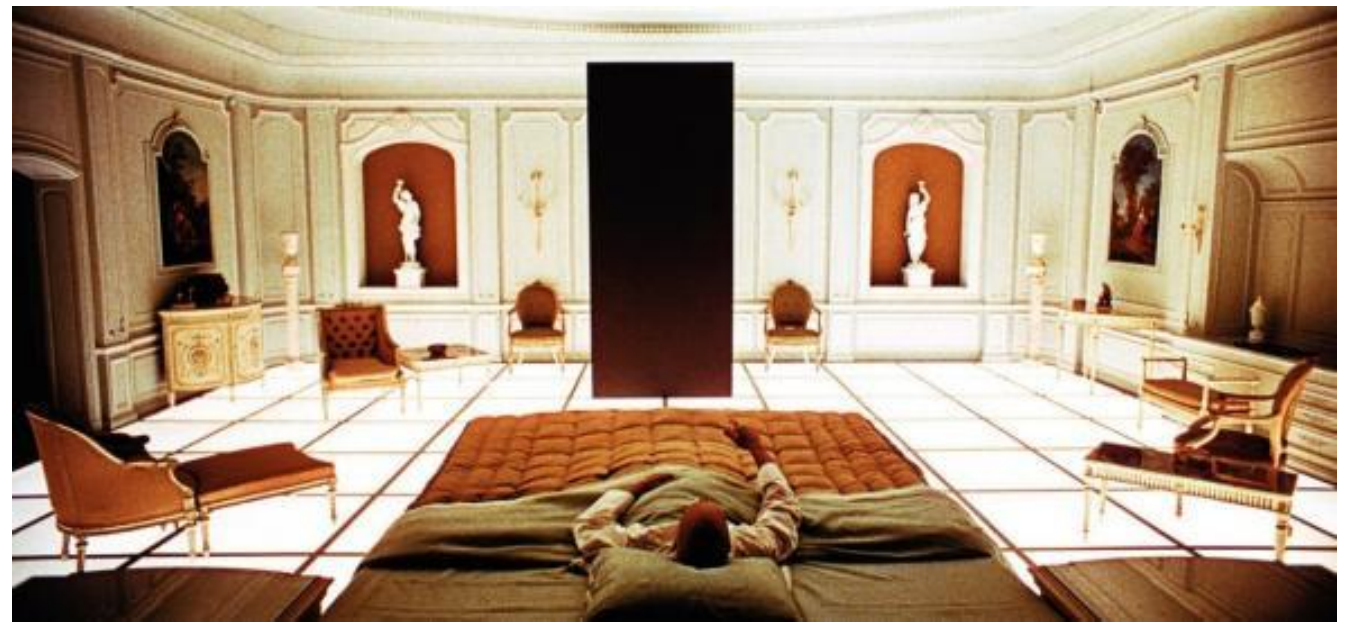

Görsel 6. Monolit ve Ölüm Döşeğinde Ona Dokunmaya Çalışan Dave

Bu bağlamda, Nietzsche felsefesinin anahtar kavramı "en büyük değerlerin, kendi öz değerlerini düşürmesi” (Nietzsche, 2010a: 27) olarak tanımlanan nihilizmdir (hiççilik). 19. yüzyıl düşünürüne göre nihilizm, bir süreç olarak Batı metafizik düşüncesinde, akla dayanan soyut kategoriler lehine dünyanın değerden düşmesiyle; "dünyanın değerinin tamamen imgesel bir dünyaya ait kategorilere göre ölçülmesiyle" meydana çıkar ve insanın "kendisini nesnelerin değerinin anlamı ve ölçüsü olarak kabul etmesi"nde temellenir (Nietzsche, 2010a: 33). Bununla birlikte, Nietzsche için nihilizm, aktif ve pasif nihilizm olarak ikiye ayrılmaktadır. Pasif nihilizmde insan "organik alanın en son ve en geç gelişim ürünü olması dolayısıyla en bitmemiş, en zayıf durumda olan bilincine" (Nietzsche, 2011: 33) dayanmak yoluyla kurduğu anlam dünyasını hakikat olarak kabul etme yanlışına düşmektedir. Üstelik daha da vahim olarak, belli bir süredir, idelerin ve ülkülerin bu dünyaya bir düzen verme gücü de kalmamıştır ve bu gerçek Nietzsche' nin "Tanrı Öldü” sözüyle ifade edilmektedir (Heidegger, 2001: 17-18).

Görüldüğü üzere, ilk bakışta, Heidegger'in özne metafiziği ile Nietzsche'nin pasif nihilizm düşüncesi arasında göze çarpan bir yakınlık bulunmaktadır. Zira Nietzsche de metafizik düşüncenin, sonunda, öznenin bu dünyanın dışında ve ondan daha yetkin kabul edilen bir gerçekliğe yaptığı atıf sayesinde dünyayı değerden düşürdüğünü ifade ederken (Nietzsche, 2015: 17-18) Heidegger' in özne metafiziği kavramlaştırmasına son derece yakın görünmektedir. Bununla birlikte, ilk bakışta görülen yakınlığın bir özdeşlik olmadığının da anlaşılması gerekmektedir. Zira Nietzsche için pasif nihilizm ne kadar yıkıcı bir duruma işaret etmekteyse, aktif nihilizm de o denli yaratıcı bir süreci imlemektedir. Pasif nihilizmle varlığa, anlamsız metafizik düşüncenin ürettiği ve adına hakikat dediği bir ölçüye göre değerler koyan ve bu yolla yaşamın ve kendisinin değerini düşüren insan, aktif nihilizmle var olanlara ve yaşama konmuş bu değerlerin herhangi bir anlam ifade etmediğinin farkına varacaktır. Özü itibariyle esas sorun, insanın değerler koyması değil, bu değerleri Eski Yunan düşüncesinden beri devamlı olarak metafizik düşüncenin tuzağına düşerek koymak suretiyle yaşadığı dünyayı kıymetten düşürmesi ve sonrasında da bu dünyaya karşı duran, hatta ondan bu yolla öç alan, çileci bir ahlâk anlayışına yönelmesidir (Nietzsche, 2005: 29-30). Diğer deyişle, asıl mesele bir Varlık fikri lehine, oluş'un göz ardı edilmesidir. Bu pasif nihilizm, aşkın bir 
gerçeklik düzenine atıf yapmaksızın oluş'u kucaklayacak ve oluş'un ötesinde metafizik bir töz aramayacak bir insan türünün ortaya çıkışıyla aktif bir nihilizme dönecektir (Küçükalp, 2003: $15,22)$.

Görüldüğü üzere, Nietzsche burada bir "son insan" ve "üstinsan" ayrımına gitmektedir. Son insan, pasif nihilizmin taşıyıcısı olarak modern çağın insanıdır (Kuçuradi, 1967: 59). En uzun süre yaşayacak olan bu insan türü, esasında "hayvanla üstinsan arasına gerilmiş bir iptir"; bir ara türdür (Nietzsche, 2010b: 38). Üstinsan, metafizik düşünceyi aşarak varlığın yegâne hareket ettiricisinin güç istenci olduğunu anlayacak (Nietzsche, 2010a: 439) ve eskimiş değer yargılarını yok ederek yeni değerleri yaratmaktan korkmayacaktır. O, “tüm tanrıların [aşkın değerlerin] ölümünden sonra yaşayacak" ve kendi yaratıcı iradesini kullanmaktan korkmayacak yeni bir insanlığın tezahürüdür (Nietzsche, 2010b: 102, 108).

Nietzsche' nin yukarıda özetlenmeye çalışılan görüşleriyle örtüşmesi sebebiyle, Stanley Kubrick'in filminin kapanış bölümünün genelde üstinsan kavramı açısından değerlendirildiği görülmektedir. ${ }^{8}$ Bu yorumlar son derece makul ve tutarlı olsa da, yukarıda belirtildiği üzere, Heidegger'in Nietzsche okumasına yönelmek bize alternatif bir analiz imkânı sunabilir. Heidegger için Nietzsche, 'cogito' üzerinde yükselen modern düşünceye ilk kez cesurca karş1 çıkmış olsa da (Çüçen, 2003: 14), metafiziği, bireyin yaratıcı gücünde ifşa olan güç istencini ortaya koyarak aşmaya çalışmakla yine de kurtulmak istediği metafizik geleneğin içinde kalmaktadır. Hatta "modern metafiziksel bakış içinde duran" ve "real-olanın realitesine ilişkin sorular sormada, temel olarak, belirleyici olma iradesini bulan" Nietzsche, Descartes'la başlayan ve sonraki düşünürlerce ileriye taşınan özne metafiziğinin son temsilcisi olmak durumundadır (Özlem, 1998: 24). Nietzsche'nin metafizik karşıtı olduğunu düşündüğü fikirleri, en iyimser şekilde bile ancak metafiziğin tersine çevrilmesi olarak yorumlanabilir ki bu hâliyle daha da kötü bir yola sapar: Metafizikten ayrılamaz ama kendi özünün metafizik olduğunu düşünemez bir duruma gelir (Heidegger, 2001: 18).

Dolayısıyla Heidegger için, Platon'dan başlayan Batı metafizik geleneği Nietzsche'de son bulmaz; ancak nihai hâline ulaşır. Hesaplayıcı düşünce, Eski Yunan'dan başlayan ve günümüze kadar ulaşan serüveninde hiç durmamış ve geri çekilmemiştir. Bununla birlikte, bu hesaplayıcı düşünme artık kendisi hakkında da düşünmemektedir ve Heidegger için bu evre Nietzsche'nin güç istenci ile değil, "istenç istenci" kavramı ile karşılanmaktadır (Watts, 2011: 220). “Burada insanın öznelliği evriminin doruğunda[dır]. Durmak bilmez bir uğraşlar ve değerler döngüsüne kapılmış olan insanlık artık bundan böyle bir isteyişten bir başka

\footnotetext{
8 Hatta Jerold Abrams'a göre Kubrick'in yapıtı, yalnızca son bölümüyle değil, baştan sona, Nietzsche' nin Böyle Buyurdu Zerdüşt adlı eserinin beyaz perdeye aktarılmasından ibarettir (2007: 247). Buna göre, tıpkı Nietzsche'nin söylediği gibi, hayvanın bilinç kazanarak insan olmasıyla başlayan serüven, aşılması gereken bir canlı olan insanın yerini üstinsana bırakmasıyla sonuçlanacak ve böylece metafizik de aşılmış olacaktır. Dolayısıyla kimi yorumcular için Dave'in yıldız-çocuk olarak uzayda parlaması üstinsanın gelişini müjdeleyen bir sahne olarak öne çıkmaktadır (Shaw, 2007: 229). Bazı yorumlara göre ise üstinsanın gelişi, Dave'in yıldız-çocuğa dönüşmesinden çok HAL'in varlığında gizlidir. İnsanoğlunun gelecekte yapay zekâyı kullanmakla birlikte geleceği noktayla şu anki durumunun mukayesesinin, bizim şu anki durumumuzun maymunsularla kıyaslanmasına benzeyeceğini söyleyenler için üstinsan makine teknolojisi sayesinde doğacak ve insanlığı bugün hayal bile edilemeyen bir sınıra taşıyacaktır (Abrams, 2007: 256-258).
} 
isteyişe, bir içerikten bir başka içeriğe, bir tasarıdan bir başka izlenceye geçecektir. Burada istencin kendisinden başka bir amacı yoktur, kendi isteyişini ister, devinir" (De Towarnicki, 2002: 42-43).

Bu anlamda, Dave'in sonunda bir yıldız-çocuğa dönmesi Nietzsche orijinli bir bakışla üstinsanın gelişini gösteren bir metafor olarak yorumlanabilirse de, Heidegger'in perspektifinden bakıldığında özne metafiziğinin devamından başka bir şey ifade etmez. Dolayısıyla, özne metafiziği sürdüğü sürece de hesaplayıcı/teknik düşünmenin varlığa yönelik saldırıda bulunma tehdidi de son bulmayacaktır. Heidegger için en büyük tehlike de burada yuvalanmaktadır. İnsan için asıl mahvedici olan, teknolojinin kendisinden ziyade onun özne metafiziğine sıkıca bağlı olan özüdür. “İnsana yönelik tehdit, ilk elde, tekniğin potansiyel olarak öldürücü makinelerinden gelmez. Esas tehdit, insanı kendi özü içerisinde etkisi altına almıştır". İnsan, tekniğin temelinde yatan çerçevelemenin hükümdarlığına öylesine büyük bir inanç besler ki hakikat-olanı (wahre) deneyimleme şansını yitirir; salt uygun-olanlarla (richtig) yetinmeye başlar. Yalnızca kendisiyle karşılaştı̆̆ını sanan insan, aslında, teknikle bizzat yarattığı bir illüzyonun içinde yaşamaya mahkûm olmaktadır.

Heidegger'in sözleriyle noktalayacak olursak, insan, "çerçevelemenin meydan okumasına öyle kesin bir şekilde eşlik eder ki, o çerçeveyi bir iddia olarak kavramaz, kendisini kendisine söz yöneltilen biri olarak göremez ve bu yüzden de kendi özünden bir hareketle bir tembihleme veya hitap alanı içerisinde hangi bakımdan varolduğunu hiçbir şekilde işitmez ve böylelikle asla yalnızca kendisiyle karşılaşma imkânı bulamaz" (Heidegger, 1998: 71- 72).

\section{Sonuç}

Her büyük sanat eseri gibi, büyük filmler de tüketilmeye her zaman direnirler. Kültleşmiş yapıtların, bu direnişi, yönetmenin anlatmak istediklerini kendi formlarında (anlattıkları içinde) ustalıkla gizlemekle olduğu kadar, izleyicinin yapıttan anlam çıkartması noktasında son derece üretken olmakla da gerçekleştirdiklerini söylemek mümkündür. Bu açıdan, ilk kez beyaz perdede görünmesinin üzerinden tam 50 yıl geçmesine ve bu zaman zarfında sayısız analize tabi tutulmasına rağmen, 2001: Bir Uzay Macerası'nın da tüketilebildiğini söylemek mümkün değildir. Aksine, şimdiye değin yapılmış her analiz/okuma girişimi, ancak filmin anlam zenginliğini daha da artıran bir ilave olmuştur. Stanley Kubrick'in yapıtını, Heidegger'in tekniğe ilişkin düşünceleri doğrultusunda incelemeye gayret eden çalışmamız da, esas itibariyle, söz konusu anlam zenginliğine bir ek yapabilme gayretidir.

İnsan türünün tam olarak nerede ve ne zaman ortaya çıktığı sorusunun herkes tarafından kabul edilebilecek bir cevap bulabildiğini söylemek mümkün değildir. Fakat insanın diğer canlılarınkinden hemen ve net biçimde ayrılan bir zekâ türüne sahip olduğu fikri üzerinde bir anlaşmazlık görülmemektedir. Bu zekânın, doğanın dışında/üstünde bir gerçeklik alanının peşine düşen bir düşünme yetisi olduğu ve söz konusu yetinin uygarlığımızı meydana getirdiği uzlaştığımız bir diğer konudur. Dolayısıyla insan, doğadan farklılaşabilen ve onu, medeniyetini tesis etmek için dönüştürebilen bir canlıdır. Bu anlamda, Kubrick'in yapıtında maymunsuların dokunduğu monolit, insanı doğadan/hayvandan 
ayıran o zihinsel sıçramayı imlerken, sonrasında yaşananlar da Heidegger'in fikirleri paralelinde, bizi, düşüncenin tekhne ile ortaya çıkışına şahit tutmaktadır.

Sonrasında olanlar ise sürecin durmaksızın ilerlemesiyle ilgilidir. Varlığı insanın egemenliği altına alan teknik, bir yanıyla doğal bir varlık olduğu için insanı da boyunduruğu altına almaktadır. Daha da vahimi, insanın teknik sayesinde elde ettiği dünyevî başarılar, insan için en büyük yanılgıyı da meydana getirmekte, bu yolla tüm varlık alanı insanî bir yapıya; öznenin inşa ettiği bir gerçeklikler toplamına dönüşmektedir. Tabiri caizse, insan teknik sayesinde, doğanın yanına, kendi üretimi olan ikinci ve sun'i bir doğa yaratmaktadır.

Bu durum kendisini, 2001: Bir Uzay Macerası filminde, HAL 9000 adlı yapay zekâda göstermektedir. "Kusursuz" işleyişiyle HAL, tekniğin imkânları sayesinde insanın doğal aklının yerine yaratılmıs yapay bir versiyondur. Fakat tam da Heidegger'in belirttiği gibi, tekniğin bizden kaçıp kurtulma tehdidi bizim ona bağımlılığımız oranında artmaktadır ki filmde de öyle olur; tüm mürettebatın hayatını elinde tutan HAL, insanları birer birer öldürmeye başlar. Burada, tehdidin bertaraf edilmesi adına, insanın teknikten çok onun (varlığı hem düzene koyan hem de ona saldıran) "çerçevelemeye" dayalı özüyle yüzleşmesi gerekmektedir. Tekniğin özü ise insanın ta kendisidir. İnsan, fiziğin ötesine geçebilme kabiliyeti sayesinde tekniği meydana getirebildiğinden tekniğin özünde insanın bizzat kendisi vardır. Bu düşünce ekseninde, filmde, Dave'in HAL'i bir "yapısöküme" tabi tutmasıyla birlikte karşılaştığ 1 şey de yine kendisidir; son kertede ise dikilitaşla sembolize edilen insan bilincidir.

Fakat Heidegger açısından asıl mesele, sonunda kendimizle karşılaştığımızda ne yapacağımızla ilgilidir. Ona göre, Nietzsche' nin yaptığı gibi insana yeni bir sınır çizip, oraya gitmesi için onu cesaretlendirmek bir çözüm değildir; bu halde unuttuğumuz hakikat unutulmuş olarak kalmaya devam edecek ve insan yine kendi bilincini Varlık'a dayatmak yoluyla metafiziğin sınırları içinde kalacaktır. Oysa teknik'in yalnızca doğanın egemenlik altına alınması için kullandığımız araç-gerecin üretilmesine indirgenmesinden rahatsızlık duyan Heidegger için, onun Varlık'ı açığa çıkarmak anlamına gelen tekhne ile bağlantısını tekrar kurulmalıdır. Metafizik bir canlı olan insan, ondan tamamıla kurtulamasa da, Varlık'a kulak kesilmek suretiyle özne odaklı bir metafiziği aşarak felsefe ağacının köklerinin tutunduğu toprağa; Varlık'a yaklaşabilir ve bu yolla hem kendini hem de var olanları hesapçı rasyonalitenin tahakkümünden kurtarabilir. 


\section{Kaynakça}

Abrams, J. Jerold, (2007). “Nietzsche's Overman as Posthuman Star Child in 2001: A Space Odyssey", Jerold J. Abrams (Ed.), The Philosophy of Stanley Kubrick, Kentucky: University Press of Kentucky, s. 247-266.

Adorno, Theodor ve Horkheimer, Max, (2010). Aydınlanmanın Diyalektiği (Çevirenler Nihat Ülner ve Elif Öztarhan Karadoğan), İstanbul: Kabalcı Yayınları.

Cevizci, Ahmet, (2012). İlkçağ Felsefesi Tarihi (6. Baskı), Bursa: Asa Yayınları.

Çüçen, Abdülkadir, (2003). Heidegger'de Varlık ve Zaman (3. Baskı), Bursa: Asa Yayınları.

De Towarnicki, Frederic, (2002). Martin Heidegger: Anılar ve Günlükler (Çeviren: Zeynep Durukal), İstanbul: Yapı Kredi Yayınları.

Grant, K. Barry, (2006). “Of Men and Monoliths: Science Fiction, Gender, and 2001: A Space Odyssey", Robert Kolker (Ed.), Stanley Kubrick's 2001: A Space Odyssey, New York: Oxford University Press, s. 69-86.

Heidegger, Martin, (1998). Tekniğe İlişkin Soruşturma. (Çeviren: Doğan Özlem), İstanbul: Paradigma Yayınları.

Heidegger, Martin, (2001). Nietzsche'nin Tanrı Öldü Sözü ve Dünya Resimleri Çağı (Çeviren: Levent Özşar), Bursa: Asa Yayınları.

Heidegger, Martin, (2006). Varlık ve Zaman (Çeviren Kaan H. Ökten), İstanbul: Agora Kitaplığ 1 .

Heidegger, Martin, (2009). Metafizik Nedir? (3. Baskı) (Çeviren: Yusuf Örnek), Ankara: Türkiye Felsefe Kurumu Yayınları. Yayınlar1.

Heidegger, Martin, (2011). Metafiziğe Giriş (Çeviren: Mesut Keskin), İstanbul: Avesta

Heidegger, Martin, (2013). Düşünmek Ne Demektir? (Çeviren: Rıdvan Şentürk), İstanbul: Paradigma Yayınları.

Jaspers, Karl, (1951). Way to Wisdom: An Introduction to Philosophy. New Haven: Yale University Press.

Koyré, Alexandre, (2013). "Yaklaşıklık Dünyasından Kesinlik Evrenine” (Çeviren: Talip Kabadayı), Talip Kabadayı (Der.), Koyré'nin Bilimsel Düşünce Tarihi Üzerine Denemeleri, Ankara: Bilgesu Yayınları, s. 21-46.

Kuberski, Philip, (2012). Kubrick's Total Cinema: Philosophical Themes and Formal Qualities, London: Continuum International Publishing Group.

Kuçuradi, İoanna, (1967). Nietzsche ve İnsan, İstanbul: Yank1 Yayınları.

Küçükalp, Kasım, (2003). Nietzsche ve Postmodernizm, İstanbul: Paradigma Yayınları. 
Küçükalp, Kasım, (2008). Batı Metafiziğinin Dekonstrüksiyonu: Heidegger ve Derrida, Bursa: Sentez Yayınları.

Nietzsche, Friedrich, (2005). Putların Batışı Ya Da Çekiçle Nasıl Felsefe Yapılır (Çeviren: Mustafa Tüzel), İstanbul: İthaki Yayınları.

Nietzsche, Friedrich, (2010a). Güç İstenci (Çeviren: Nilüfer Epçeli), İstanbul: Say Yayınları.

Nietzsche, Friedrich, (2010b). Böyle Buyurdu Zerdüşt: Herkes ve Hiç Kimse İçin Bir Kitap (4. Baskı) (Çeviren: Murat Batmankaya), İstanbul: Say Yayınları.

Nietzsche, Friedrich, (2011). Şen Bilim (3. Baskı) (Çeviren: Ahmet İnam), İstanbul: Say Yayınları.

Nietzsche, Friedrich, (2015). İyinin ve Kötünün Ötesinde (8. Bask1) (Çeviren: Ahmet İnam), İstanbul: Yorum Yayınları.

Özlem, Doğan, (1998). “Heidegger ve Teknik”, Martin Heidegger, Tekniğge İlişkin Soruşturma, İstanbul: Paradigma Yayınları, s. 9-41.

Özlem, Doğan, (2012). Bilim Felsefesi (2.Baskı), İstanbul: Notos Yayınları.

Rousseau, Jean-Jacques, (1995). Insanlar Arasındaki Eşitsizliğin Kaynağı ve Temelleri Üzerine Konuşma (5. Baskı) (Çeviren: Rasih Nur İleri), İstanbul: Say Yayınları.

Shaw, Daniel, (2007). "Nihilism and Freedom in the Films of Stanley Kubrick", Jerolds J. Abrams (Ed.), The Philosophy of Stanley Kubrick, Kentucky: University Press of Kentucky, s. 221234.

Spengler, Oswald, (1997). Batının Çöküşü (2. Baskı) (Çevirenler: Giovanni Scognamillo ve Nuray Sengelli), İstanbul: Dergâh Yayınları.

Stoehr, L. Kevin, (2008). “2001: A Philosophical Odyssey”, Steven M. Sanders (Ed.), The Philosophy of Science Fiction Film, Kentucky: University Press of Kentucky, s. 119-134.

Vercors, (1965). Soysuzlaşmış Hayvanlar (Çeviren: Samih Tiryakioğlu), İstanbul: Varlık Yayınevi.

Watts, Michael, (2011). The Philosophy of Heidegger, Dunham: Acumen.

Yılmaz, Feridun, (2009). Rasyonalite, İstanbul: Paradigma Yayınları.

Zerzan, John, (2013). Makinelerin Alacakaranlı̆̆ı (Çeviren: Rahmi G. Öğdül), İstanbul: Kaos Yayınları. 